УДК 632.92

(C) 2012

Білявський Ю. В., кандидат біологічних наук

Полтавський інститут АПВ ім. М. І. Вавилова НААН

\title{
ХЛІБНИЙ ЖУК-ВУСАЧ (DORCADION CARINATUM PALL.) У ПОСІВАХ КУКУРУДЗИ
}

\section{Рецензент - доктор сільськогосподарських наук, професор П. В. Писаренко}

\begin{abstract}
Подано результати фітосанітарного моніторингу агроиенозів кукурудзи у Полтавській області, яка $\epsilon$ лідером з ї̈ посівних площ і показників урожайності в Україні протягом останніх п'яти років.

Вперше за останні десятиріччя відмічено появу та поширення хлібного жука-вусача (Dorcadion carinatum Pall.) у посівах кукурудзи. Висвітлено біологічні особливості шкідника, обгрунтовано причини його масового поширення влітку 2011 року в умовах Лівобережного Лісостепу України.

Наведено дані про шільність шкідника та особливості пошкодження ним рослин. Визначені чинники, щчо мають безпосередній вплив на розвиток, поширення хлібного жука-вусача та можливі втрати врожаю кукурудзи від нього. Надані методичні рекомендації щзодо осіннього та весняного обстежень сільгоспугідь і контролю чисельності pimoфara.
\end{abstract}

Ключові слова: жук-вусач, личинка, заселення, чисельність, икідливість, кукурудза, біологія, захист.

Постановка проблеми. Кризові явища в економіці (виведення з обробітку значних площ орної землі, загальне зниження рівня агротехніки, порушення рекомендованих сівозмін і насичення ïх окремими комерційними культурами, зменшення обсягів та порушення регламентів застосування засобів хімічного захисту рослин) сприяють активному поширенню комплексу шкідливих організмів [2]. Подальше розорювання земель також призводить до порушень і різких змін у спеціалізованих ентомокомплексах агроценозів. На ці зміни передусім реагують грунтові шкідники. Так, у господарствах Полтавської області в 2011 році відмічали значне пошкодження рослин кукурудзи личинками хлібного жукавусача. Шкода від них виявилася досить несподіваною. Катастрофічних спалахів масового розмноження хлібного жука-вусача раніше відмічено не було. Тому вивчення динаміки його чисельності, поширення та шкідливості є актуальним і своєчасним.

Аналіз основних досліджень і публікацій, у яких започатковано розв'язання проблеми. Вперше цього шкідника описав полтавський ен- томолог М. В. Курдюмов [5]. Вчений Полтавської дослідної станції О.В. Знаменський описав біологічні особливості шкідника та методику обстеження грунтової ентомофауни [3, 4]. Вважається, що несподіваному зростанню щільності личинок хлібного жука- вусача сприяє зростання забур'яненості полів, на яких відсутня будь-яка агрономічна діяльність протягом декількох років. Осередками існування та первинними стаціями його масового розмноження можуть бути перелоги, толоки, вигони, межі, пустирі й навіть невеличкі ділянки, забур'янені пирієм [12]. Шкідник може зустрічатися на чорноземах, глинистих і солончакових грунтах [16].

Мета досліджень та методики їхнього проведення. Зважаючи на економічні збитки, спричинені діяльністю шкідника, головною метою досліджень було вивчення й уточнення особливостей біології, динаміки чисельності личинок жука, їх поширення та шкідливість. У господарствах області проводили розкопки пошкоджених рослин кукурудзи та збір личинок шкідника, яких ми визначали в умовах лабораторії агроекології та захисту рослин Полтавського інституту АПВ ім. М. І. Вавилова НААН за допомогою бінокуляра МБС-10, використовуючи апробовані визначники комах [3-5].

Результати досліджень. Міжнародна наукова назва шкідника - Cerambycidae Latreille, 1802. Хлібний жук-вусач належить до класу комах; загін - жорсткокрилі; родина: вусачі $[14,15]$. Загальна чисельність родини становить близько 26000 видів. В Україні зустрічається близько 280 видів [1,6]. Вусачі є одними з найбільш вивчених серед жорсткокрилих. У фаховій літературі зустрічаються наступні назви хлібного жука-вусача: Dorcadion (Carinatodorcadion) carinatum carinatum Pallas, 1771, або Cerambyx carinatus Pallas, 1771; синонім - Lamia pigra Schoenherr, 1817; Dorcadion (Carinatodorcadion) carinatum m. cinereopubescens Breuning, 1946.

Російська назва - коренеїд хлібний, або вусач грунтовий хлібний [13]. Англійська назва Long-horned beetle. 
Рід Dorcadion Dalm. Коренеїд чорний - Dorcadion carinatum Pall. (Pigrum Schh. - польовий скрипун [7-9]. Плавільщиков Н. Н. [7] відмічав близько 20 видів вусачів. Згідно з визначником, жук-вусач - коренеїд чорний (Dorcadion carinatum Pall.) має подовжену форму, майже без волосяного покриву.

Екологія. Стацією шкідника слугує степ, цілинні та перелогові ділянки. Роль вусачів у природних екосистемах полягає в тому, що, будучи консументами першого порядку, вони $є$ невід'ємними компонентами ланцюгів живлення. У процесі коеволюції організмів сформувалася трофічна мережа зв'язків між автотрофами i гетеротрофами, в яку вусачі включаються на стадіях личинки, лялечки та імаго. Так, у процесі механічної обробки цих стацій личинки, які вціліли, починають харчуватися корінцями культурних злаків і можуть нанести значну шкоду. Подальшого заселення зораних ділянок зазвичай не відбувається, поскільки жуки краще відкладають яйця на неораних землях. Пошкоджують кукурудзу, пшеницю, ячмінь, овес і дикорослі злаки. Жуки з'являються рано навесні після танення снігу i незначного прогрівання грунту. Відмічено, що найбільш ранніми $\epsilon$ види Dorcadion. Переміщуються вони переважно вранці та в другій половині дня, в спекотний період ховаються під грудками грунту, в тріщинах, під камінцями. Харчуються злаками, поїдаючи листя i перегризаючи паростки біля самого грунту.

Біологія. Хлібний жук-вусач (Dorcadion carinatum Pall.), або вусач земляний хлібний, характеризується відсутністю білої шовної смуги і надзвичайно сильно розвиненим плечевим ребром досить довгих надкриль. Голова - 3 подовженою боріздкою, а вусики досягають середини надкриль або трохи заходять за неї, - їх перший членик помітно довший другого; у самки вони ледь не досягають середини надкриль. Жук чорний, слабо блискучий, покритий сіруватим пилом. Лапки іноді злегка бурі, недовгі. Волосяний покрив розвинений досить слабко, і зазвичай жук виглядає голим. Довжина жука 15-23 міліметрів. Крила сильно редуковані. Поверхня надкриль усіяна цятками, частіше вони одноколірні, бурі або чорні. Жуки зазвичай виходять із лялечок восени й зимують у грунті. Іноді зимують також і лялечки. Яйця відкладають у квітніна початку травня на рослини пирію, товстоногу, пшениці ярої та озимої, у вигризений щілиновидний отвір у піхві листка біля самої поверхні грунту. Ембріональний розвиток продовжується 15-17 діб. Відродження личинок відбувається наприкінці травня - початку червня. Через 15-20 діб після відродження личинка покидає стебло й переміщується в грунт, де харчується корінцями злаків. Личинки товсті, $з$ маленькою головою й сильно розширеними грудними сегментами (особливо перший). На тілі $є$ хітинові пластинки, що утворюють овальні фігури. Личинки - білуватого кольору, циліндричні; вусики рудиментовані, верхні щелепи великі, товсті, заокруглені $[10,11]$. Вони мають довжину до 20 мм, живуть в орних, толочних та цілинних землях. Залягають вони близько до поверхні грунту, поблизу розгалужених корінців різних злаків, у тому числі й хлібних. Личинки зимують у грунті (на глибині 4-5 см), досягають повного розвитку й заляльковуються тільки восени наступного року. Зазвичай тривалість стадії лялечки - 30-40 діб.

Аналіз літературних даних показав, що масове розмноження шкідника відмічали у 1912, 1924, 1956, 1978, 1989, 2000, 2011 роках. Так, у 19971998 рр. шкідника спостерігали у північній Осетії (2-5 липня), у 2009 році - в Харківській (м. Люботин - 22 травня) та Дніпропетровській обл. (травень 2010 р. та 8 липня 2011 р.). У Полтавській області (2011 рік) шкідника відмічали в посівах кукурудзи у Зінківському районі (с. Хрипки, ФГ «Мільченко О. П.»). Причиною цього явища було розоране поле площею 6 га, на якому впродовж 6-7-ми років не вирощували польові культури. Після виникнення дружніх сходів, у фазу 3-5-ти листків кукурудзи, окремі рослини почали жовкнути й відставати в рості. Пошкодження рослин спостерігали місцями - по 4-5 шт. у рядку. Середня кількість пошкоджених рослин 7-10\%. Відсоток випавших (зав'ялих) рослин $-1-2 \%$. Кількість личинок в місцями 3-5 особин $/ \mathrm{m}^{2}$. У фазі 6-7-ми листків личинка вже не шкодила й знаходилася на глибині 12-15 сантиметрів. Відповідні випадки відмічено також у Кременчуцькому районі (с. Вільна Терешківка, ТД «Арніка»). Пошкодження рослин кукурудзи відмічено на рівні 2-3\%. На полях Холдингу «Миронівський комбінат хлібопродуктів» заселення личинками жука-вусача спостерігали на рівні $50 \%$, у рядках - по 5-7 пошкоджених рослин. Одиничні випадки відмічено також у фермерських господарствах Кобеляцького району.

Заходи боротьби. Для обмеження поширення жука-вусача та запобігання його шкідливості на сільськогосподарських посівах злакових культур слід дотримуватися наступних заходів: знищення на орних землях заростей пирію та інших злаків; використання ловчих канавок, по периметру сільськогосподарських угідь, що межують із 
можливими резерваціями вусача, які жуки не в змозі подолати, тому що вони позбавлені крил; застосування протруйників насіння інсектицидної дії $[11,12]$.

Висновки. Хлібний жук-вусач поширений в агроценозах із порушеною культурою землеробства, особливо на забур'янених полях, де пере-

\section{БІБЛІОГРАФІЯ}

1. Бартенев $A$. Ф. Обзор видов жуков-усачей (Coleoptera: Cerambycidae) фауны Украины [Текст] / А. Ф. Бартенев // Вісник Харківського ентомологічного товариства. - 2003 (2004). T. 1-2. - № 11. - С. 24-43.

2. Білявський Ю. В. Стан популяції озимої совки (Scotia segetum Schiff.) в агроценозах кукурудзяно-соєвого поясу Полтавської області за дії чинників різної природи [Текст] / Ю. В. Білявський, В. М. Чайка, М. Д. Мельничук [та ін.] // Аграрна наука і освіта. - 2008. - Т. 9. - № 3-4. - С. 50-57. 3. Знаменский $A$. В. Насекомые вредящие полеводству [Текст] / А. В. Знаменский // - Ч. 1. Вредители зерновых злаков. - Полтава. - 1926. С. $180-181$.

4. Знаменский А. В. Пособие для производства обследования энтомофауны почвы [Текст] / А. В. Знаменский // ЦУП ВСНХ. СССР. - К. 1927. - C. 22-23.

5. Курдюмов Н. В. Главнейшие насекомые, вредящие зерновым злакам в Средней и Южной России [Монография] / Курдюмов Николай Васильевич / Полтава. - Элекрич. типогр. Д. Н. Подземского. 1913. - С. 79-80.

6. Лобанов A. Л. Систематический список усачей (Coleoptera, Cerambycidae) фауны CССР [Текст] / А. Л. Лобанов, М. Л. Данилевский, С. В. Мур- важають багаторічні злакові. Розорювання таких ділянок активізує міграцію цього шкідника на суміжні сільськогосподарські посіви злакових культур. Дотримання сівозміни, своєчасне та якісне протруювання насіння препаратами інсектицидної дії сприятиме ефективному захисту хлібних злаків.

зин // Энтомологическое обозрение. - 1981. T. 1. - № 60 (4). - С. 784-803.

7. Плавильщзиков Н. Н. Определитель насекомых. Краткий определитель наиболее обычных насекомых Европейской части Союза ССР [Монография] / Николай Николаевич Плавильщиков// Изд-е третье. - ГУПИ Министерство просвещения РСФСР. - М., 1957. - С. 236-248.

8. Порчинский И. А. О вредных насекомых южной России [Текст] / И. А. Порчинский // СПБ, Изд-е Д-та Земледелия. - 1879. - С. 5-32.

9. Холодковский Н. А. Курс энтомологии, теоретической и прикладной [Монография] / Н. А. Холодковский // Том II, изд-е третье, перераб. С.-Петербург, Издание А. Ф. Девриена. - 1912. C. 209-231.

10. http://bibliotekar.ru/brokgauz-efron-u/34.htm 11. http://crimea.fotopage.ru/data/displayimage. php?album $=681 \&$ pos $=1$

12. http://macroid.ru/showphoto.php?photo $=43185$ 13.http://rarespecies.ru/nasekomye/zhestkokrylye/us ach-zemlyanoj-xlebnyj-dorcadion-carinatum-pall 14. http://www.cerambycidae.net/danilevsky.htm 15. http://www.cerambyx.uochb.cz/check_ussr3.htm 16. http:/www.lamiinae.org/index.php?pg=fgrp \&id $=44464 \& 1 \mathrm{lg}=\mathrm{en}$ 